This item was submitted to Loughborough's Research Repository by the author.

Items in Figshare are protected by copyright, with all rights reserved, unless otherwise indicated.

\title{
Grounding theories of place and globalisation
}

PLEASE CITE THE PUBLISHED VERSION

http://dx.doi.org/10.1111/j.1467-9663.2010.00614.x

\section{PUBLISHER}

Blackwell Publishing Ltd (Article @ The Author / Tijdschrift voor Economische en Sociale Geografie @ 2010 Royal Dutch Geographical Society KNAG)

\section{VERSION}

SMUR (Submitted Manuscript Under Review)

\section{PUBLISHER STATEMENT}

This work is made available according to the conditions of the Creative Commons Attribution-NonCommercialNoDerivatives 4.0 International (CC BY-NC-ND 4.0) licence. Full details of this licence are available at: https://creativecommons.org/licenses/by-nc-nd/4.0/

\section{LICENCE}

CC BY-NC-ND 4.0

\section{REPOSITORY RECORD}

Antonsich, Marco. 2019. "Grounding Theories of Place and Globalisation”. figshare.

https://hdl.handle.net/2134/16127. 


\title{
Grounding theories of place and globalization
}

\begin{abstract}
In the 1990s, under the perception of increasing transformations brought about by globalization, scholars started investigating what happened to the notion of place. Among others, the views of Manuel Castells, Robert Sack, and Doreen Massey contributed to construct an opposition between a parochial, bounded, and reactionary notion of place versus a global, unbounded, and relation one. This latter view, under the label of 'progressive sense of place', has since become a dominant paradigm in geography. The present article aims to ground these theoretical arguments in relation to how people understand place today. Qualitative empirical information collected in four different regional contexts in Western Europe confirms the discursive existence of the above opposition. Yet, it also challenges the ways in which notions of thickness/thinness and bounded-ness/unbounded-ness relate to the regressive or progressive character of place.
\end{abstract}

\section{INTRODUCTION}

"What happens to the notion of place in this age of globalization?” This question was asked more than a decade ago by Doreen Massey (1995, p. 46). Her answer is well-known among geographers. The specific character of place has not changed; yet, this specificity is no longer - if it has ever been - the product of internalized histories and embedded cultures, but the product of ongoing processes of material and social interconnections with the wider world (Massey, 1991, p. 29). Since then the notion of 
place as an unbounded, plural, dynamic, and multi-scalar socio-spatial construct has attracted a great deal of interest among human geographers (Staeheli, 2003; Cresswell, 2004). Among them, Amin (2002) has pushed the discussion even further by arguing that the new spatialities of globalization should be understood as relational processes and network forms of organization beyond any geographical scale. Within this perspective, places still matter, but no longer as bounded sites of geographical proximity articulated through single or multiple scales.

This notion of place as unbounded and relational is today perceived as a sort of dominant paradigm (Castree, 2004). To be true, this paradigm does not go without criticism, as some authors have argued that bounded places are not per se regressive or reactionary, whereas unbounded, trans-local places are not per se progressive (Ibid., p. 150). More than a decade ago, for instance, May (1996) showed that the diversity which characterizes some neighborhoods of London (out of which Massey’s work originates) might be articulated by some individuals only in terms of a 'flaneuristic' desire for the exotic, which falls short of creating a real 'global sense of place', as socio-ethnic boundaries continue to remain in place. Focusing on indigenous communities and their defense of place, Escobar (2001) has also expressed concerns about the elimination of borders, as these allow for place-based forms of resistance against global capital. A similar focus characterizes also Castree’s (2004) critical discussion of relational perspectives on place. Like Escobar, Castree also defends the right of indigenous communities to 'differential geographies', which emphasize 'distinctions from' rather than 'relations with' the wider world. These place-bound movements, the argument goes, cannot be accused of being regressive, as they actually defend and empower local indigenous communities. In these instances, transnational connections do not erase local boundaries, but actually strengthen them 
(Ibid., p. 159). More recently, Tomaney (2007), by recalling the importance of the phenomenological link between people and places, has critically engaged the view of place as merely the local articulation of global flows and has, instead, stressed the importance of place as a bounded material and symbolic unit.

The present article aims to rejoin this debate, by analyzing qualitative information regarding the impacts of globalization on places which I personally collected in four different regional contexts across Western Europe. My approach departs somewhat from Massey’s, as my primary focus is not on how scholars, but people understand place in the age of globalization. In this sense, it adopts a less normative ('we should think of place as...') and more grounded approach, which aims at bridging theoretical speculations with commonly held views on place. More specifically, I will focus on the views of those whom, for reasons of brevity, I shall call 'local elites', i.e., individuals holding a political, institutional, or social position within the local places in which they live.

Three major theoretical arguments will be discussed in relation to these 'voices from the ground': Massey’s 'progressive sense of place' and its associated 'powergeometry’; Castells' (2000) twofold logic of 'space of flows' and 'space of places'; and Sack's (1997) notion of 'thick' and 'thin' places. These are neither the only theoretical efforts to conceptualize place in the age of globalization nor even the most recent ones. Yet, their long-lasting impact on geographical studies makes them particularly relevant for the purpose of this research.

Among the potential disclaimers which impact on the scope of this article, I should mention one in particular. The article does not indeed engage with the notion of place in all its dimensions, but it privileges the analysis of place as locale, which, using Agnew’s (2002, p. 16) words, is defined as "the [physical] setting in which 
everyday life is most concentrated for a group of people”. It leaves out, among others, issues of scale and addresses only partially the notion of sense of place.

After presenting the three major theoretical arguments by Massey, Castells and Sack, the article focuses on local elites' views about how globalization has been affecting the place where they live. These views are then analyzed in the light of the three above mentioned scholarly arguments and these latter are in turn critically discussed in relation to the empirical findings.

\section{THEORIES OF PLACE IN THE AGE OF GLOBALIZATION}

A common denominator among some of the principal theories which have tried to conceptualize the notion of place in the age of globalization is the emphasis on 'openness', connections, networks, and flows. The most renowned theory along these lines is Massey’s (1991, 1995) 'global sense of place'. Simply put, her argument is that, even less so than in the past, place today cannot be defined as a distinct, coherent, and bounded locale, associated with a culturally given community. On the contrary, place should be understood as "a meeting-place, the location of the intersections of particular bundles of activity spaces, of connections and interconnections, of influences and movements”, which crisscross in a unique way at any given point in time and space (Massey, 1991, p. 28; 1995, p. 59). According to Massey, this conception can successfully reject the charge that place is an intrinsically 'reactionary' concept, built around boundaries which separate an 'inside' from an 'outside', 'us’ from ‘them’ (Massey, 1991, p. 28). Massey’s progressive or global 
sense of place is indeed unbounded, dynamic, and open to multiple networks of material and social relations, linked with and linking to the wider world.

The emphasis on openness, connectivity and network characterizes also another major interpretation of place in the age of globalization. Castells’ (1997; 1998; 2000) trilogy on the rise of the information society has been widely echoed by geographers. Particularly appealing to them has been Castells' twofold spatial logic - 'space of flows' and 'space of places' - which, according to the Catalan sociologist, characterizes our contemporary society. The presence/absence of 'physical contiguity' is what defines these two logics. While 'space of flows', the dominant spatial logic of the world economy, is indeed characterized by global circuits of electronic exchanges, networks, nodes and hubs, 'space of places' embodies an opposite logic (still very present today, even in the most technologically advanced societies), which refers to how people live their lives. People, in fact, do still live in spaces perceived as places 'whose form, function, and meaning are self-contained within the boundaries of physical contiguity' (Castells, 2000, p. 441-42, 453). Even in the present information age, the new 'space of flows' do not take over the traditional 'space of places', but the two in fact coexist. The problem, then, is how to understand the simultaneous working and interweaving of these two spatial logics. Contrary to a rather consolidated interpretation among urban and economic geographers (Thrift 1996; Swyngedouw 1997; Brenner 1999; Jessop 2000; Dematteis 2001), which sees the role of local places in conditioning (and being conditioned by) globalizing processes, Castells seems unable to reconcile these two dimensions. Instead, he points to a 'structural schizophrenia' between the a-historical, horizontal 'space of flows' on the one hand and the deep vertical relations of people with their places on the other hand (Castells, 2000, p. 459). In this sense, Castells reproduces the idea of a globalization led by 
technocratic-financial-managerial elites, disconnected from, if not in opposition to, the interests, needs and lives of people and their places (Castells, 2000, p. 446). It is exactly this interpretation - resonating with the language of a strictly Marxist opposition between capital and society - which indirectly opens the way to a conceptualization of place as a locus of resistance (Routledge 1996; Cox 1997; Pile and Keith 1997).

A third major contribution to the understanding of place in the age of globalization is associated with Robert Sack (1997), whose perspective is largely imbued with a phenomenological approach (Tuan 1974a; Relph 1976; Buttimer and Seamon 1980). For Sack, the human being is indeed a homo geographicus, i.e. a person who cannot exists without places - which, in turn, cannot exist without human beings (Sack, 1997, p. 141). Sketching a sort of genealogy of place, Sack distinguishes between 'thick places', which are the dominant socio-spatial formation in simple or pre-modern societies, and 'thin places', which reflect the spatial segmentation of life brought about by modernity. Thick places are characterized by a time-space concentration of human activities. They are organic, self-contained, allencompassing spaces, within which nature, meanings and social relations are closely interwoven. In this sense, as Sack simply puts it, they are 'thick' with meaning (Sack, 1997, p. 8). Thin places, on the contrary, are the segmented, but interconnected places around which our modern life is organized: home, school, work-place, etc. They are functional spaces, which are often freely chosen by the individual, but whose meanings are increasingly 'thinned-out'. Neither thick nor thin places are for Sack desirable settings, as the former might be associated with practices and discourses of exclusion of the Other and the latter with a cultural homogenization which reduces all local differences and makes all places look alike. The ideal place for Sack is, 
therefore, one which is 'not too thick' and which has permeable boundaries that allow for the exchange, rather than the simple preservation of differences (Sack, 1997, p. 8).

Openness, connectivity, mobility and exchange emerge from the accounts of these three authors as the key features of place in the age of globalization. These features are, for Massey, what make a place 'progressive', while for Sack they allow for the 'liberation' or the 'empowerment' of the subject, as this latter can increases her/his social contacts and self-awareness (Sack, 1997, p. 10). The absence of these same features, instead, might construct a notion of place as 'thick', 'regressive' and 'reactionary’ (Massey and Sack), resisting the 'dis-placing' logic of global mobility, connectivity and flowing (Castells). Between these two notions of place there is an ongoing tension, which has been aptly captured in form of a paradox by Harvey (1989): globalization makes places appear less stable and secure than before and this, in turn, makes people feel more attached to their places. Building further on Harvey’s insight, Massey has investigated the different ways in which people are immersed within the 'space of flows' and has suggested the existence of a 'power-geometry' (Massey, 1993). While in fact some people, because of their education or welfare, are highly mobile and they can easily jump from one place (or identity) to another, other people do not have the same social or material capital to escape their local condition (identity) and, therefore, they often reproduce a defensive and protective attitude towards the place where they live (Massey, 1995, p. 48-49 - see also Morley, 2001, p. 427).

In the next section, I will discuss the views of some local elites collected in different European regional contexts in order to engage, from an empirical perspective, the binary oppositions discussed above: bounded/unbounded, progressive/regressive, thick/thin. 


\section{RESEARCH DESIGN}

The present article relies on a larger research design, based on both quantitative and qualitative methods, aimed at analyzing the relationship between territory and identity in the age of globalization. Within the scope of this research, territory was conceptualized at four scales: local, regional, national, and European. In the present article I will only focus on the local scale, i.e. the village/town where people were born and/or spent most of their lives. This is the 'place', i.e., a portion of geographic space filled with social relations, meanings and identities (Duncan, 2000), which will be here investigated in the light of the comments of the respondents regarding the impact of globalization on the places where they lived.

Two caveats are here in need of specification. First, the term 'globalization' is both widely used and broadly defined and as such its meaning remains highly contested (Dicken, 2000). In the present study, globalization is not used as an analytical category, but as a context which prompted the conversations. Moreover, what globalization means was left open during the interviewing process. ${ }^{1}$ Second, this study does not focus on ordinary people in general, but on individuals holding political, institutional, or social positions at the local level - henceforth called, for reasons of brevity, 'local elites'. There is not the pretension here that these views represent those of the general public. The choice to focus on this category of people as a way to explore 'voices from the ground' was only made on the hypothesis that they could offer a richer source of qualitative data - something which I believe turned out to be true. 
Overall, I conducted 99 in-person individual semi-structured interviews. Politicians constituted the large majority of the interviewees and were selected in order to have a representative sample of all the parties existing in the local context. Gender was unevenly represented, as men (71) largely outnumbered women (28). Age varied widely and so did education, with a large number of respondents holding a university degree and a few interviewees lacking even a high-school degree. Information about income was not collected, yet personal notes gathered during the interviews make possible to affirm that the majority of the interviewees belonged to the middle-class, with few cases in the upper or lower classes.

Interviews were administered in the native language of the respondents, as the Author is in fact fluent in English, French, and Italian. In Pirkanmaa, the language of the interviews was instead English - a language generally mastered by the respondents. ${ }^{2}$ Interviews were digitally recorded, transcribed and coded following an inductive approach, i.e., codes were not generated on the basis of an a priori theory, but on the observation of recurring patterns (Bryman and Burgess, 1994) and then analyzed following what Crang (1997, p. 188) calls ‘analytic induction' - an approach which, echoing the grounded theory method, relies on the iterative process of going back and forth between original data and theoretical concepts in order to reach successively more abstract categorizations.

Interviews were administered between May 2005 and January 2006 in four regional case-studies in Western Europe (i.e. the area of the European Union, before the two last enlargements): Languedoc-Roussillon (France); Pirkanmaa (Finland); Lombardia (Italy); and North East of England (United Kingdom) (Fig. 1). 
Fig. 1. The regional case studies
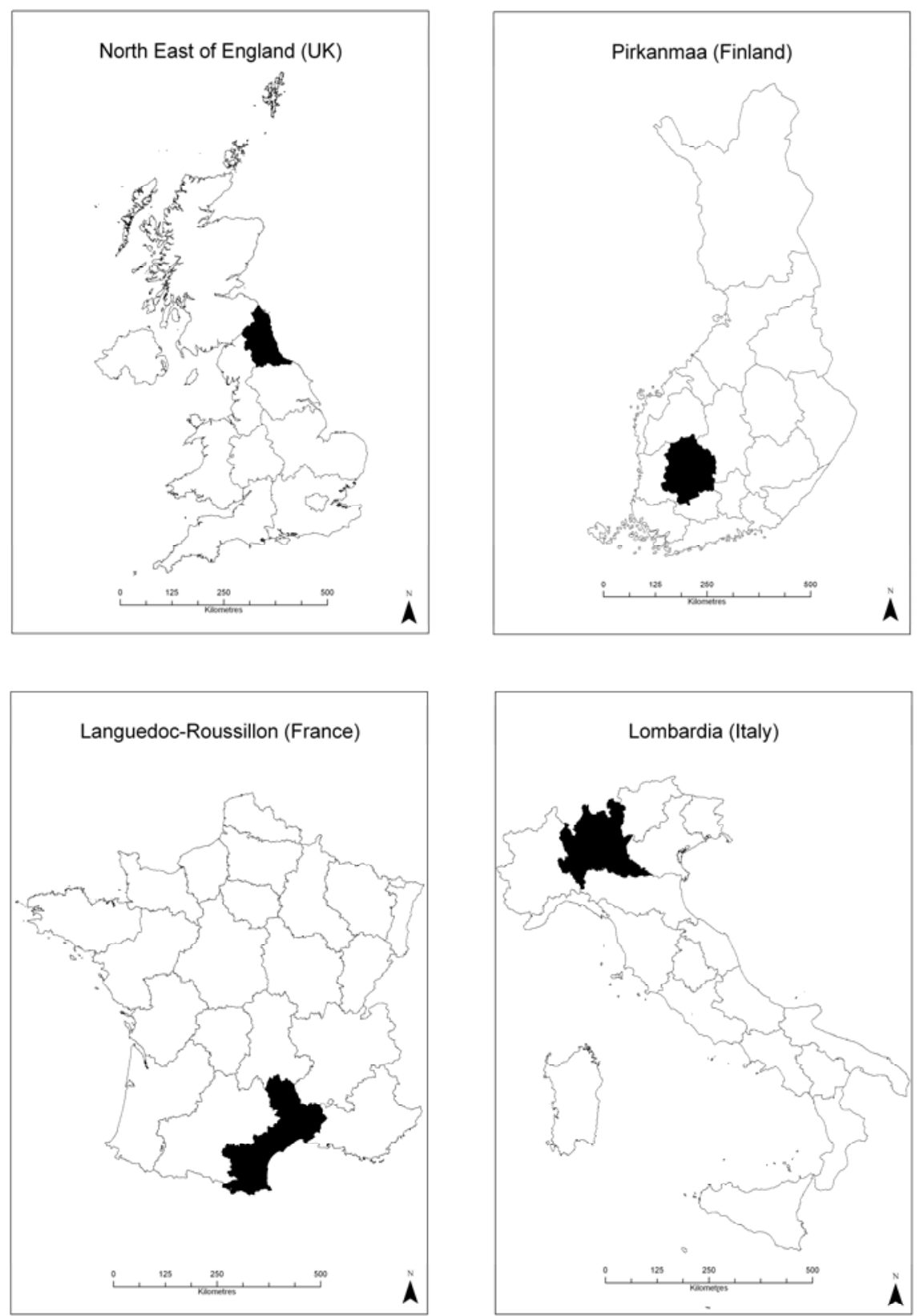

These regions were selected on the basis of a preliminary statistical analysis on Eurobarometer (Eb 60.1 - 2003) survey data for European attachment cross-tabulated with Eurostat (2001-2003) data for regional GDP measured in terms of purchasing power parity. ${ }^{3}$ The choice of clustering regions in terms of their socio-demographic indicators (independent variables) was taken in order to avoid the selection bias that 
would result from sampling regions on the basis of territorial attachment, i.e. the dependent variable (King et al., 1994).

The four selected regional case-studies offer a good representation of the different socioeconomic, political, and geographical conditions of Western Europe. Lombardia is one of the richest regions in Europe and a major 'engine' of the European economy, followed by Pirkanmaa, whose regional capital, Tampere, has long been on the forefront of the knowledge economy and information society (Castells and Himanen, 2002). Down the ladder, the North-East of England is a region still heavily affected by the closure of the coal mining sector, with a relatively high level of unemployment, high numbers of people living on benefits and low level of education (Colls and Lancaster, 1992). Similarly, Languedoc-Roussillon is one of the poorest regions of France, with an economy essentially based on services for the domestic market and therefore rather impermeable to the effects of global economic competition (Giband, 2005). This view was also reproduced by the respondents and it explains why French voices appear only occasionally in the present article. Politically, Lombardia is a region traditionally conservative, whereas the North-East of England has been conventionally ruled by the Labour Party. Similarly, the LanguedocRoussillon has long been a stronghold of leftist parties (Genieys, 1998), giving way more recently to centrist and rightist (National Front) political formations. A unique coalition of right and left parties ('Brothers in Arms') characterizes instead the major political scene in Pirkanmaa. Finally, from a geographical perspective, the four selected case-studies represent both the North and the South of Western Europe, reflecting also different attitudes towards the process of European integration, from positive (Lombardia, Languedoc-Roussillon) to less positive (Pirkanmaa) or overtly skeptical (North-East of England) views. 
In the next sections, this qualitative information will be analyzed in order to engage the notion of place in the age of globalization 'from the ground'. This information will be organized under two different headings, 'thickness' and 'thinness', which, rather than simply reproducing Sack’s homonymous distinction, aim to capture more broadly the binary opposition discussed above, between notions of socio-cultural rootedness and 'bounded-ness', on the one hand, and notions of functionality, connectivity and mobility, on the other hand.

\section{THICKNESS}

While French interviewees, as mentioned earlier, tended to downplay the role of globalization in the transformation of place, the majority of Italian, Finnish and English respondents agreed that a sense of local attachment and identity has increased in recent decades due to globalization, however defined. The point here is not just to confirm the paradox of globalization mentioned by Harvey, but to explore the relationship between globalization and the increased 'thickness' of the locale. In this sense, evidence coming in particular from Lombardia, the North East of England, and Pirkanmaa is rather revealing.

Both in Lombardia and in the North East of England globalization has been perceived to have negatively impacted the local economy. In and around Como, the area chosen to administer the interviews in Lombardia, respondents lamented a significant loss of jobs in the major local industry (textile manufacturing). While at the beginning of the early 1950s there were 50,000 workers occupied in this industry, in 2005 this figure had more than halved. Respondents pointed to the competition 
with China and its cheap textile products which have forced local factories to close down, prompting a generalized crisis in the local economy as a whole.

A similar gloomy picture also emerged in the interviews collected in and around county Durham and Newcastle, in the North East of England. Having already been hit severely, in the 1980s, by the decision of the conservative government of Margaret Thatcher to close down the mining and ship-building sectors, this area has only partially recovered itself with the creation of new manufacturing jobs (Colls and Lancaster, 1992; Tomaney, 2006). In the 1990s, attracted by a cheap labor force and financial incentives (both national and European), some multinational companies have decided to build their own manufacturing plants in this region. Yet, various economic representatives interviewed in the North East of England pointed to the vulnerability of jobs in branch plant economies as they would tend to disappear easily during periods of economic restructuring - a point sadly confirmed by the unemployment rate reached by the North East during the present economic recession. ${ }^{4}$

It is therefore not surprising that, in both regional contexts, globalization triggered a negative sentiment among respondents. As put by an Italian officer of Como’s Chamber of Commerce:

Globalization is having a strong impact: not as much as in terms of delocalization. There is a strong feeling of disorientation. From my perspective, the majority of people look at globalization ... I am talking about small and medium entrepreneurs, who are exposed to international competition without a sort of protection which existed before... so what is it left of globalization? The perception of something which gives you troubles and displaces you, because you are unable to react, you are unable to turn it to your own advantage. 
Feelings of disorientation translate into a sense of defensiveness which in turn feeds the thickness of place with parochial, reactionary, and inward-looking identity narratives. In the case of Lombardia, the Northern League, ${ }^{5}$ more than any other Italian political parties, has capitalized on these fears, reproducing forms of introverted localism, as reflected for instance in the following quote by an anonymous local leader of the Northern League in Como:

The goal of the Northern League has been to stress the local rootedness... both in cultural terms, by recalling strong identity principles, by stressing the importance of the dialect, of vernacular languages, of local traditions and habits, and in economic and trade terms... the battle, let's call it this way, that the League carries against Chinese products... so that we can limit and stop this unfair competition from China and protect [our] enterprises. [...] I notice that there is a continuous and dramatic return to the sentiment of belonging to one's territory, to one's locale, to the principles and the values of our society. [On the other hand, I notice] a constant opening to this multiculturalism, to this integration without rules, without principles, without control which I think it would lead to the decay of what our traditions, our origins, our sense of belonging to [our] territory have been ... and the society will impoverish.

'Our' is here casted against someone/something, portrayed in the form of a foreign immigrant or an 'unfair' economic competition. The 'return to the origins', to a place believed to be un-corrupted by any foreign elements becomes a powerful rhetoric, which promises to alleviate the anxiety of those who find themselves dis- 
placed within a changing society. The locale transforms into an inward-looking locus of resistance, providing feelings of protection and security, against what is 'out there'. This, however, is particularly ironic, given the fact that the prosperity of Lombardia has been largely based on its economic openness to the global markets (Mainardi, 1998).

A similar reaction was evident also among the respondents in the North East of England. In this case, place was celebrated as a repository of past memories, filled with a sense of close-knit communities, as for instance evoked by a County Durham councilor:

Things are just getting bigger all the time. People in old days they had their own village identity and that seems it is gone.

Interviewer: Is it gone?

Yes, to a great extent

Interviewer: Why?

Because it's a mini version of this globalization, where we have the media... Where I live was a mining area and each village had its own mine and people used to live in streets opposite to the mine ... all... the life was based around their work and there was not...nothing else, basically.

This comment reveals the uneasiness about accepting a present in which the traditional link between modes of economic production, settlements, and communities is no longer. Having greatly suffered from the restructuring of the 1980s and feeling the precariousness of the present economic situation, people in the North East of 
England, as a consequence, tend to take refuge in the memories of their lost past. As a leader of the Liberal Democrats in the North East observed:

For many people there is a nostalgic mentality about the coal mining industry; and coal mining was a horrible, dirty and dangerous, uncomfortable, fearful thing and I am really delighted that is gone. But of course other people do want to glorify those days - they are in grief for the lost communities, people having a... very... great depth of social networks within a very small space. And very, very little knowledge of what was going on outside that space.

Mourning the past is what keeps these people attached to their own places and what generates 'thick' narratives of place often casted in opposition to the socioeconomic transformations brought about by the neo-liberalism of the Thatcher government first and then by the increasing global economic competition. ${ }^{6}$

Some of the voices heard both in Lombardia and in the North East of England clearly reveal a 'thick' view of place, which is also self-enclosing, defensive, inwardlooking, and reactionary. Yet, it would be erroneous to think that thickness per se is associated with these characters and, therefore, intrinsically regressive. Empirical evidence collected in Pirkanmaa, in fact, suggests that a sense of local rootedness can also be open to the 'space of flows', without loosing in terms of cultural embeddedness. Moreover, this local rootedness or thickness can also be reinforced by the successful integration of the locale within the world economy.

Overall, interviewees in Tampere (Pirkanmaa) talked positively about globalization, a view justified by the creation of new jobs and the establishment of two public-sponsored programs, e-Tampere (2000-2005) and Creative Tampere 
(2006-2011), which have contributed to transform this city-region into an information society (Kostiainen and Sotarauta, 2003). ${ }^{7}$ All the interviewees affirmed that a sense of local identity has increased, mainly as a side-effect of the confidence generated by the successful performance of Tampere in the global economy. As one representative of the party representing the Swedish minority in the City Council of Tampere observed:

Where you have decreasing work then I think you have more negative attitude[s] towards globalization because people think or I think they think that the reason to lose jobs is globalization and so on [...]. But in places like Tampere, Oulu, where you have very much positive effect[s] on globalization, whatever you think globalization is, positive effects, positive attachment and I think positive, as I said, patriotism they are connected to the 'life is good' [attitude].

From this perspective, it is exactly the integration into the global network ('space of flows') which contributes to strengthen the identity of the locale ('space of places'). These two spatial registers are therefore not mutually exclusive, but actually one (the 'space of places') is built over the other ('space of flows'). This does not simply mean that, as already noted by various authors (Scott, 2001; Scott and Storper, 2003), the locale is the first engine of economic globalization. It also means that, in this globalized age, the relationship between the locale and the people who inhabit it is not necessarily one of dis-placement, producing self-enclosed, inward-looking, parochial spaces of resistance. On the contrary, this relationship can actually be fed by the mutual interaction between these two spatial logics and give way to forms of local rootedness which are open and actually constituted through the interaction with the 
wider world. In this sense, it is correct to affirm that Tampere offers an empirical confirmation of Massey's notion of 'progressive sense of place'.

Yet, it is important to note than even when this local thickness is (re)produced by a connection with the space of flows and networks, the very act of bounding and its associated narratives of 'us’/'them' are not wished away - as somewhat implied by Massey (1991, p. 28). Interviewees in Pirkanmaa did not abdicate to their own cultural embeddedness, which manifested itself, among other things, in relation to the ironic reference to jokes stereotyping the cultural specifics of people living in the Tampere region. These narratives of a cultural 'we', however, did not prevent a narration of place in progressive, relational, and open terms. This point can be better elucidated by referring to the comment of an Italian interviewee, a representative of labor unions:

Interviewer: So, when identity is attached to a territory, does it prevent the integration of diversity?

Not at all. On the contrary, to a certain extent, it favors it, in the sense that... if I have a home, I can open the door, that is to say I can offer you something. You too, if you have built a home, you can offer me something, but if we don't have a home, what are we going to offer to each other?

This discursive use of 'home' as a metaphor for a sense of collective identity is rather telling of the importance that people attach to place (however 'progressive', i.e. open to a constellation of socio-economic networks it might be) as a locus of local rootedness, familiarity, security, and identity, along the lines discussed by Tomaney (2007). In other words, a sense of local identity or rootedness cannot escape the logic 
of distinguishing 'we' from others, if any such identity has to have any meaning in the everyday life (Castree, 2004, p. 155). In the rush to celebrate everything which is relational, topological, and un-bounded, this is a point which is often obliterated. A 'progressive sense of place', one which is open to the interaction with the wider world, can certainly coexist with discourses of 'bounding', as long as what is bounded remains open to the exchange with the outer/Other.

\section{THINNESS}

Respondents talked of place not only in thick terms, by referring to some sort of shared local history, culture, traditions, and memories. They also described their relation to place in 'thin' terms. In this case, place was said to fulfill the needs of the individual in terms of everyday life activities (working, transportation, leisure, etc.). As such, place becomes a fungible space, one where the individual can freely choose to be in or out, thus generating a sense of 'empowerment' and 'liberation' (Sack, 1997). It is important to note, though, that these functional and mobile places did not trigger less of a sense of attachment than places narrated in thick terms. Consider, for instance, the three following quotes, coming respectively from a Liberal Democrat member of Durham City Council, a representative of an association of French entrepreneurs and a Social Democrat member of the Council of Tampere Region:

I live in one of the villages. My mother lives in the city [Durham]. When I was 12 we moved into the city, but at the moment I live in Sherburn, which is 3 miles out, so I think I have the best of both worlds, because it's a beautiful city, it 
takes me 10 minutes to drive into the city, but at the same time I can walk my dog in the countryside... and the village community is very nice... I am lucky: my parents came to such a nice place to call home really.

People become attached to their 'pré-carré' [clearly defined and well defended space], as we say in France to their garden, to 'chez eux', to the sun, which is good here, but I would say... they become attached to this, to a quality of life [...]. I have chosen, also by chance, to live in Narbonne, which is a small town of 50,000 inhabitants. I feel good there and... well, I think I will still live in Narbonne when I retire.

I drive $35 \mathrm{~km}$ everyday

Interviewer: Why don't you move to Tampere?

Well, I like to live in a place where I have nature. When I step out of the door, I have my garden there. I don't like very big cities.

In all the above three cases, the relationship between individual and place is one based on a personal choice. Place is not articulated in terms of a collective 'we', defined in cultural or historical terms, but in terms of an individual ' $\mathrm{I}$ ', who freely decide where to root her/himself. Wherever some form of cultural thickness exists, this rarely impinges on the individual to the point that s/he starts portraying her/himself as a member of this cultural 'we'. More likely, instead, this local thickness might add an aesthetic dimension to the personal enjoyment of place, as, for instance, in the case of relatively wealthy people in the North East of England moving 
to the countryside, attracted by the idyll of rural landscape and quiet life (Horton, 2008).

These thin places, as implicitly suggested by the interviewees, are often constructed around the notion of quality of life; a 'feeling good' factor, which in turn might also generate a sense of local attachment, as empirical studies both in sociology (Guest and Lee, 1983) and in environmental psychology (Stokols and Shumaker, 1981; Williams and Vaske, 2003) have also shown. Often chosen on a rational, functional, utilitarian basis (e.g. working, studying, retirement, etc.), these places, by being the locus where the everyday life of the individual unfolds, become indeed imbued with a sense of 'topophilia' (Tuan, 1974b), an affective and emotional attachment. As a Finnish entrepreneur and member of the centre-right National Coalition Party (Kokoomus) put it:

Let's go back to the question [why people come to Tampere]...rationality yes, but they stay because of emotional questions.

It is important to note that the logic behind the existence of thin places is not just one related to the personal choices of the individual. Logics of capital accumulation and re-production, in fact, often intervene in the process of 'thinning-out' places (Ong, 2007). In this sense, quality of life as a key dimension for an individual to settle in certain places might therefore be a much less politically and economically 'neutral' choice than what one might think. In a context of 'glocalized' economies (Swyngedouw, 1997), locales compete to attract the brightest minds which can be successfully put at work in the never ending processes of capital accumulation and reproduction (Mitchell, 2003). Within this competition, marketing strategies aimed at 
‘selling places’ (Kearns and Philo, 1993; Ward, 1998) acquire a key dimension. It is significant, for instance, that among the four regional case studies analyzed in the present article, two of them have clearly put in place this type of strategies. In the North East of England, the Regional Development Agency (RDA) has launched in 2005 an image campaign aimed at attracting 'talented people' (and investments) on the basis that the region is 'an excellent place to live, work, study, visit and do business'. ${ }^{8}$ Since the late 1990s, Tampere has also been on the forefront of a similar marketing campaign, as recalled for instance by one Finnish interviewee, who in the past played a major role in this campaign:

We realized in the late 1990s that if we really want to be a successful city we should attract young talented people here. For example, we created the marketing system which marketed Tampere as a university study place for young people all over Finland...no city in Finland at that time had that kind of marketing activity. But we also thought how we can root them, what we can offer them so they really feel like at home here. [...] Nowadays competing with cities is not only related [to] companies and jobs, but more and more [to] these environment and services and in this game the main question is how you can create interesting and safe and nice environment.

On the one hand, the thinning-out of places, as suggested by Sack (1997, p. 10), can be empowering, as it liberates the individual from the socio-cultural cage which often thick places create; yet, on the other hand, it might be consonant with neoliberalist discourses and practices and, as such, generate new boundaries of exclusion, based on income and/or education - rather than culture, like in the case of thick 
places. From this perspective, thin places might be less 'progressive' than what expected. Examples from the French and the English case studies illustrate this point further.

In Languedoc-Roussillon, the transformation of the local economy from the viticulture sector into a service economy (Giband, 2005) has generated a large middle-class, who has settled down in the former rural villages, in search of a better quality of life and cheaper property prices. At the same time, attracted by a pleasant climate and coastline, a conspicuous number of retired people have flocked to the region, settling down in the same villages or demanding the construction of new settlements along the coast. In both cases, the social texture of close-knit communities, structurally attached to their locales in virtue of their economic activity (thick places), has been disrupted and new thin places, chosen because of their quality of life, have emerged. In both cases, a new social divide has materialized, drawing lines of territorial exclusion, as clearly indicated, for instance, by the following French interviewee, a professor at the University of Montpellier I:

One of the games which are played today behind the scene is that the economy of the coastal area, which is formed by municipalities which get richer and richer... they aim, in a very inflexible way, to keep out the population which is poor...[this is even truer] in a context of crisis of the 'banlieues' [suburbs]...this is the gated community, without HLM [public housing], without workers, without youngsters: this is the big trend.

Interviewer: Where, in France?

On the littoral of the Languedoc. They are municipalities formed mainly by retirees. For a middle-class who wants to spend their retirement undisturbed, 
identity is all but surveillance. And this explains why [people who espouse] this big trend have always refused to join the metro area [Montpellier's metropolitan area]. Because to join the metro area is to identify yourself with the urban. And the urban means to identify with social problems which come from [the absence of] work. We are not a city, we are a summer resort.

The poor, the unemployed, the working-class people are 'out of place' (Cresswell, 1996) in these new thin places, often chosen on the basis of their quality of life. This obviously generates a socio-spatial divide along the lines suggested by Massey's (1993) notion of 'power-geometry'. On the one hand, there are people who have the social and material capital to choose the place (and the identity) they want and, on the other hand, there are those who lack these resources and are stuck in their own places, developing defensive, inward-looking, and parochial forms of resistance and identity (see Castells, 1997, p. 8-9, 65-66).

The case of the North-East of England presents a quite similar picture. Even in this case, an increasing number of houses in the old mining villages have been bought by middle-class or retired people, similarly attracted by the beauty of the countryside and cheap property prices. These 'incomers' are not always welcomed by native inhabitants, some of whom might feel both discouraged and dispossessed by their arrival, as illustrated, for instance, by the following quote of an English interviewee, representative of an independent party in County Durham:

A lot of people coming in the villages, you know [they say] "that's nice there" and then you know ...it would be good if these people would have come for building a factory there...200 jobs...but "we did not come here for that, we came 
here for the scenery”... of course, they got high salaries [...]. You have a steady declining population, plus young people cannot afford to buy a house there...too expensive.

These two cases clearly expose relevant political, economic and social consequences associated with the thinning-out of places. The risk is not only, as Sack puts it, of loosing cultural diversity or even a sense of collective identity, as in thin places everybody would become an atomistic individual. The risk also is that the rise of these new 'empowering', 'liberating' places would either produce or reinforce new spaces of exclusion, marginalization, and dispossession. In this perspective, any debate about the progressive/regressive characters of thin/thick places becomes fuzzy.

\section{CONCLUSION}

What has changed from the time Massey was interrogating, some fifteen years ago, the notion of place in the age of globalization? A quick answer would be: not

much. Scholars have continued investigating place by privileging the relational, topological approach mainly theorized by Massey. Emphasis on connectivity, networks, nodes, and flows has fed (and has been fed by) discourses on plurality, openness, diversity, hybridity, etc. On the contrary, bounded notions of place have been discarded, along with their supposedly intrinsic cultural embeddedness. While the former notion of place has been heralded as progressive, the latter has been implicitly branded as regressive. 
Empirical evidence collected in four different locations in Western Europe does not challenge this analytical view of place. On the contrary, it confirms the discursive existence of places as progressive (open to the wider world) and regressive (selfenclosing, defensive, inward-looking, and reactionary). Yet, what the evidence seems to challenge is what scholars generally think might lead to a progressive or regressive sense of place. In fact, a discursively bounded place, i.e. a place where discourses of a collective cultural 'we' exist in relation to a given locale, should not necessarily be regarded as regressive. When analyzed against globalization, it seems that this sociospatial thickness might become regressive when the locale is perceived to be unable to integrate itself into the globalized world. In this case, as Castells argues, two opposite, irreconcilable spatial logics collide, as the 'space of places' in which people live their lives and which is characterized by a logic of physical proximity comes to be felt as disconnected from and actually threatened by the new logic of 'space of flows'. This perception reinforces discourses and practices of closure, defense and resistance against anything/anyone that is thought to exist 'out there'. On the contrary, when people believe that globalization can work to their own advantage, the sense of cultural embeddedness is not necessarily activated against someone/something, and the logic of spatial flows can actually be welcomed as a source of local empowerment, challenging Castells' argument on the irreconcilability of these two spatial logics. A reinvigorated sense of local pride can be predicated on the awareness of a successful integration into the space of flows. This thickened cultural 'we' is one which can open up positively (progressively) to the wider world. Yet, in the process of being constituted through this interaction, it does not relinquish its sense of bounded-ness. Simply acknowledging the global connections which intervene in the construction of place does not per se make this place unbounded. Empirical evidence 
seems indeed to suggest that people might perceive these connections as reinforcing a sense of collective identity articulated in terms of a close association to a given locale.

On the opposite side, the same evidence seems to suggest that thinner places, i.e. places which are less imbued with thick socio-cultural meanings, are not necessarily more progressive. Thin places might respond to the desire for a better quality of life of individuals who have the cultural or material resources to decide where they want to live. In this sense, as noted by Sack (1997, p. 10), thin places might be liberating and empowering. Yet, they should not be regarded as progressive per se. The point here is not only, as observed by Massey and Harvey, that this freedom of choice is not evenly distributed and, as people remain trapped into a given locale, they are more likely to develop a thick, reactionary, and defensive identity. It is also that the very existence of some thin places might be accompanied by forms of socio-spatial exclusion, as these places selectively choose the parts of the wider socio-economic world with which they connect. Examples from Languedoc-Roussillon and the North East of England illustrate this point.

Further empirical research is therefore needed to analyze the forms of (a selective) closure of place towards the wider constellation of social and material relations which constitute the world. Similarly, discourses and practices which bound people together and which generate thick meanings of place should be empirically analyzed in the ways in which not only resist, but also interact with this world, rather than being merely discarded on the basis of their bounded-ness. Even in the present age of globalization, there is no ultimate evidence that everything which is bound is to melt into a space of flows, networks, relations, etc. Recent theoretical reflections suggest that it is indeed in the interplay of various spatial formations, both bounded and unbounded, that a fruitful line of investigation into contemporary socio-spatial 
processes might lie (Jessop et al., 2008). A global sense of place cannot escape a moment of closure and any theorization on its progressive character has therefore to come to terms with the different forms (progressive and regressive) of this closure, rather than simply wishing closure away.

\section{ACKNOWLEDGMENTS}

The field work part of the present study was made possible thanks to a financial grant obtained from the National Science Foundation (USA): Doctoral Dissertation Research Improvement grant no. 0503405, conferred on 30 Dec, 2004. Thanks also to Phil Jones (GEES, University of Birmingham) for drawing the maps of the regional case studies.

\section{References}

AGNEW, J. (2000), The road to Padania: the Northern League and Italian regionalism. International Journal of Urban and Regional Research 24, pp. 227-231.

AGNEW, J. (2002), Place and Politics in Modern Italy. Chicago: University of Chicago Press.

AMIN, A. (2002), Spatialities of Globalisation. Environment and Planning A 34, pp. 385-399.

BRENNER, N. (1999), Globalisation as reterritorialisation: The Re-scaling of urban governance in the European Union. Urban Studies 36, pp. 431-451. 
BUTTIMER, A. and SEAMON, D. (eds) (1980), The Human Experience of Space and Place. London: Croom Helm.

BRYMAN, A. and BURGESS, R.G. (eds) (1994), Analyzing Qualitative Data. London: Routledge.

CASTELLS, M. (1997), Information Age. Economy, Society and Culture. The Power of Identity. Oxford: Blackwell.

CASTELLS, M. (1998), Information Age. End of Millennium. Oxford: Blackwell.

CASTELLS, M. (2000): Information age. The Rise of the Network Society. Oxford: Blackwell.

CASTELLS, M. and HIMANEN, P. (2002), The Information Society and the Welfare State. Oxford: Oxford University Press.

CASTREE, N. (2004), Differential geographies: place, indigenous rights and 'local' resources. Political Geography 23, pp. 133-167.

COLLS, R. and LANCASTER, B. (eds) (1992), Geordies. Roots of Regionalism. Edinburgh: Edinburgh University Press.

COX, K.R. (ed) (1997), Spaces of Globalization. New York: Guilford.

CRANG, M. (1997), Analyzing qualitative materials. In: R. FLOWERDEW and D. MARTIN, eds., Methods in Human Geography, pp. 183-196. Edinburgh: Longman.

CRESSWELL, T. (1996), In place, out of place. Minneapolis: University of Minnesota Press.

CRESSWELL, T. (2004), Place: a short introduction. Oxford: Blackwell.

DEMATTEIS, G. (2001), Shifting cities. In: C. MINCA, ed., Postmodern Geography, pp. 113-128. London: Blackwell. 
DICKEN, P. (2000), Globalization. In: R. JOHNSTON, R. et al., eds., The Dictionary of Human Geography, pp. 315-316. Oxford: Blackwell.

DUNCAN, J. (2000), Place. In: R. JOHNSTON, R. et al., eds., The Dictionary of Human Geography, pp. 582-584. Oxford: Blackwell.

ESCOBAR, A. (2001), Culture sits in places: reflections on globalism and subaltern strategies of localization. Political Geography 20, pp. 139-174.

GENIEYS, W. (1998), La 'grande transformation' du Midi Rouge. Pôle Sud 9, 3-6.

GIBAND, D. (2005), Languedoc-Roussillon. In: B. GIBLIN, ed., Nouvelle Géopolitique des Régions Francaises, pp. 733-781. Paris: Fayard.

GIORDANO, B. (2000), Italian regionalism or 'Padanian' nationalism - the political project of the Lega Nord in Italian politics. Political Geography 19, pp. 445471.

GUEST, A.M. and LEE, B.A. (1983), Sentiment and evaluation as ecological variables. Sociological Perspectives 26, pp. 159-184.

HARVEY, D. (1989), The Condition of Postmodernity. Oxford: Blackwell.

HORTON, J. (2008), Producing Postman Pat: The popular cultural construction of idyllic rurality. Journal of Rural Studies, 28, pp. 389-398.

JESSOP, B. (2000), The Crisis of the National Spatio-Temporal Fix and the Tendential Ecological Dominance of Globalizing Capitalism. International Journal of Urban and Regional Research 24, pp. 323-360.

JESSOP, B., BRENNER, N. and JONES, M. (2008), Theorizing sociospatial relations. Environment and Planning D 26, pp. 389-401.

KEARNS, G. and PHILO, C. (1993). Selling Places. London: Pergamon.

KING, G., KEOHANE, R.O. and VERBA, S. (1994), Designing social inquiry. Princeton, NJ: Princeton University Press. 
KOSTIAINEN, J. and SOTARAUTA, M. (2003), Great Leap or Long March to knowledge economy: Institutions, actors and resources in the development of Tampere, Finland. European Planning Studies 11, pp. 416-438.

MAINARDI, D. (1998). L'Italia delle regioni: il Nord e la Padania. Milano: Bruno Mondadori.

MAY, J. (1996), Globalization and the politics of place: place and identity in an inner London neighbourhood. Transactions of the Institute of British Geographers 21, pp. 194-215.

MASSEY, D. (1991), A global sense of place. Marxism Today June, pp. 24-29.

MASSEY, D. (1993), Power-geometry and a progressive sense of place. In: J. BIRD et al., eds., Mapping the Futures, pp. 59-69. London: Routledge.

MASSEY, D. (1995), The conceptualization of place. In: D. MASSEY and P. JESS, eds., A place in the world? Places, cultures and globalization, pp. 45-77. Oxford: Open University and Oxford University Press.

MITCHELL, K. (2003), Educating the national citizen in neoliberal times: from the multicultural self to the strategic cosmopolitan. Transactions of the Institute of British Geographers 28, pp. 387-403.

MORLEY, D. (2001), Belongings: Place, space and identity in a mediated world. European Journal of Cultural Studies 4, pp. 425-448.

ONG, A. (2007), Please stay: Pied-a-Terre subjects in the megacity. Citizenship Studies 11, pp. 83-93.

PILE, S. and KEITH, M. (eds) (1997), Geographies of Resistance. London: Routledge.

RELPH, E. (1976), Place and Placelessness. London: Pion. 
ROUTLEDGE, P. (1996), Critical geopolitics and terrains of resistance. Political Geography 15, pp. 509-531.

SACK, R. (1997), Homo Geographicus. Baltimore: The Johns Hopkins University Press.

SCOTT, A.J. (ed) (2001), Global City-Regions. Oxford: Oxford University Press.

SCOTT, A.J. and STORPER, M. (2003), Regions, globalization, development. Regional Studies 37, pp. 579-593.

STAEHELI, L. A. (2003), Place. In: J. AGNEW et al., eds., A Companion to Political Geography, pp. 158-170. Oxford: Blackwell.

STOKOLS, D. and SHUMAKER, S.A. (1981), People in places: a transactional view of settings. In: J.H. HARVEY, ed., Cognition, Social Behavior, and the Environment, pp 441-488. Hillsdale, NJ: Lawrence Erlbaum Associates.

SWYNGEDOUW, E. (1997), Neither global nor local: 'glocalization' and the politics of scale. In: K.R. COX, ed., Spaces of Globalization, pp. 137-166. New York: Guilford Press.

THRIFT, N. (1996), Spatial Formations. London: Sage.

TOMANEY, J. (2006), North East England: A Brief Economic History. Newcastle: NERIP.

TOMANEY, J. (2007), Keeping a beat in the dark: narratives of regional identity in Basil Bunting's Briggflatts. Environment and Planning D 25, pp. 355-375.

TUAN, Y-F. (1974a), Space and place: Humanistic perspective. Progress in Geography 6, pp. 211-252.

TUAN, Y.-F. (1974b), Topophilia. A Study of Environmental Perception, Attitudes, and Values. New York: Columbia University Press.

WARD, S.V. (1998), Selling Places. London: E \& FN Spon. 
WILLIAMS, D.R. and VASKE, J.J. (2003), The measurement of place attachment.

Forest Science 49, pp. 830-840.

\footnotetext{
${ }^{1}$ In the interviews, globalization was repeatedly articulated in terms of its economic dimension (i.e., increasing international competition) and, to a relatively less extent, social dimension (i.e., increasing number of foreign immigrants).

${ }^{2}$ I personally translated the original quotes in French and Italian into English. If at times this translation might appear poor is because it aims to reproduce the oral tone of the original conversation. This applies also for the quotes from the Finnish interviewees, which are purposely reproduced as they were originally heard.

${ }^{3}$ Additional information on the method of the selection of the regional case-studies is available from the Author upon request.

${ }^{4}$ According to the Labour Force Survey, between March 2008 and September 2009 the unemployment rate in the North East has risen from 6.6\% to $9.5 \%$ - the second highest rate in the UK (Office for National Statistics, www.statistics.gov.uk, accessed on 2 December 2009).

${ }^{5}$ The Northern League has emerged in the 1980s, under the leadership of Umberto Bossi, as an autonomist party, claiming the separation of Northern Italy - called 'Padania' - from the rest of the country (Agnew, 2000; Giordano, 2000). Recently, the party, which has joined the government Berlusconi in a center-right coalition, has switched from a separatist to a federalist policy, but it remains a populist, anti-immigrants, anti-globalization, and anti-Europe party.

${ }^{6}$ It is significant that every July, in Durham, the Durham Miners' Association organizes the Miners' Gala. The old mining villages' banners are taken in a parade along the streets to Durham's Cathedral, where a mass is celebrated. This gala was first staged in 1871 and since then, despite the fact that today no miners work anymore, every year thousands of people attend the event: re-enacting the past as a way to cope with the void of the present.

${ }^{7}$ E-Tampere was a program established by the city of Tampere in 2000 with the ambitious aim of becoming the world's leading city in the development of the knowledge society. At the end of the scheduled term (2005), e-Tampere might not have reached this goal, but it has successfully created a network of people involved in business, government and university activities which has positively impacted the local economy (interview with an eTampere's project manager, 28 September 2005). In 2006, e-Tampere has been substituted by another program, Creative Tampere, which aims to build over the past experience of $e$-Tampere to give practical shape to the idea of information society (see http://www.luovatampere.fi).

${ }^{8}$ One North East, Regional Image Campaign: http://www.onenortheast.co.uk/page/regionalimagestrategy.cfm (last accessed 2 December 2009).
} 